to Davos for treatment. The disease was checked, but pulmonary fibrosis left him with a legacy of ill-health, which was all the more tragic to a man who had a great interest in out-door sport and big game shooting, and had been a distinguished oarsman at Oxford.

Returning to Oxford in 1913 he began a series of investigations into the part played by the kidneys in the regulation of the composition of the blood, but this work was soon interrupted by the outbreak of the War of 1914-18. He volunteered at once, and was given a commission in the R.A.M.C. on September 1, 1914. Serving in France and Belgium he was in the following year awarded the Military Cross and was mentioned in despatches. He was wounded at Neuve Chapelle. Later in the War he was associated with Haldane and Meakins in an investigation into the after-effects of war-gas poisoning. When peace came he was appointed reader in clinical physiology at Oxford. His further investigations included work on various aspects of the physiology of respiration, on the function of the kidney, on some problems of general metabolism, and, more recently, he was engaged on a critical examination of methods for ascertaining the output of the human heart. $\mathrm{He}$ was again, and most appropriately, associated with Haldane as joint author of a new edition (1935) of Haldane's book "Respiration". With a clear appreciation of the relationship of physiology to medicine he was largely responsible for initiating a practical course of human physiology in the Final Honour School of Physiology, which led to the publication of "Human Physiology; a Practical Course", now in its second edition, of which he was joint author. For the Physiological Society he prepared a subject index of the first sixty volumes of the Journal of Physiology, and he succeeded John Mellanby in the editorship for a few years of Physiological Abstracts, a task in which his expert knowledge of the international decimal system for the classification of scientific papers proved of great service.

He leaves a widow, and a son, Major Charles Priestley.

C. G. Douglas.

\section{Dr. Alexander Bowman}

AMong the men of science who have guided fishery research in Scotland, and they form a distinguished company, Dr. Bowman was marked by a grasp of the practical problems of the fisheries and of the scientific efforts which must lie behind the solution of these problems.

Yet scientific work was not his earliest notion of a career. He began by helping his father in a prosperous business in Aberdeen, and then proceeded to take the normal training for a teacher at the Free Church Training College in that city. It was after these first essays that he decided to enter the University, and to study for a degree in science. He graduated in the University of Aberdeen with distinction in zoology, and was awarded the Fullerton research scholarship in natural science, but before the completion of its tenure he resigned on being appointed naturalist to the Fishery Board for Scotland.

There he worked in collaboration with Sir D'Arcy
Thompson, scientific member of the Fishery Board, and his early activities were centred upon the research steamer Goldseeker and the amassing of enormous collections made during the periodic voyages of that vessel, which were to help in explaining the movements of waters, the changes of salinity, the distribution of food materials, and thus to interpret the movements of the fishes themselves. Later he applied himself with great success to the solution of practical fishery problems, such as the elucidation of the enormous fluctuations in fish supplies, the forecasting of future yield, the effect of the size of mesh in influencing escapes of undersized fish, and so on. During these years he worked almost single-handed and with great devotion, spending month after month at sea in the stormy northern waters, laying the foundation of his vast knowledge of the fisheries in their scientific and practical aspects. In 1908, Dr. Bowman obtained the degree of D.Sc. at the University of Aberdeen for a thesis containing some of his pioneer work in the experimental study of fishing methods, notably on the otter trawl and its effect on the stocks of fish. His experience of fishery research was widened by periods of study in Denmark and Germany.

On the sudden death of Mr. Nelson, who had just succeeded Dr. T. Weymss Fulton as scientific superintendent of the Fishery Board for Scotland, Dr. Bowman was appointed to fill the post in 1923. In this position he developed his earlier researches and enlarged the scientific staff of the Board. An excellent example of the value of his methods is to be seen in his work upon the haddock, which has formed the foundation of the most thorough-going knowledge of one of our most important food fishes. He considered that one of his greatest honours was his appointment in 1925 as chairman of the Northern North Sea Committee of the International Council for the Exploration of the Sea, but the choice was not surprising, for his colleagues at home and abroad had the greatest respect for his knowledge and judgment, and he was properly regarded as one of the best fishery experts of his time.

Dr. Bowman's training as a teacher was made use of by the University of Aberdeen when it appointed him lecturer in the scientific study of fisheries, and in Aberdeen and the surrounding district he conducted classes in marine zoology for teachers and delivered popular lectures on natural history. In 1933 illhealth compelled him to resign from his post, and a lingering illness ended his life on January 14, when he was in his sixty-fifth year.

\section{WE regret to announce the following deaths :}

Prof. F. A. P. Aveling, University professor of psychology in King's College, London, on March 6, aged sixty-five.

Miss Ethelind Gardiner, for thirty-five years secretary of the Royal Society for the Protection of Birds, on March 1.

Sir George Grierson, O.M., K.C.I.E., the Oriental scholar and compiler of the "Linguistic Survey of India", on March 7, aged ninety. 